\title{
Heterosis analysis in relation to drought tolerance in rice land races and their genotypes
}

\section{R. Ushakumari, R. Muthukamatchi and G. Thamodharan*}

Department of Plant Breeding and Genetics, Agricultural College and Research Institute, Madurai- 625104, INDIA *Corresponding author. E-mail: srig852@gmail.com

Received: September 12, 2014; Revised received: November 06, 2014; Accepted: December 12, 2014

Abstract: An experiment was conducted in rice to study the heterosis for drought tolerance and grain yield in 24 hybrids developed from six landraces viz., Kallurundaikar, Kuliadichan, Kuruvaikalangiam, Mattaikar, Nootripathu and Vellaichithiraikar used as lines and four high yielding varieties viz., PMK 3, MDU 5, ASD 16 and ADT 36 used as testers for physio-morphological traits by Line $x$ tester analysis. The experimental results revealed that the hybrids viz., Nootripathu / MDU 5, which had significant standard heterosis for eight characters namely days to $50 \%$ flowering, plant height, productive tillers, root length, root dry weight, root : shoot ratio, harvest index and grain yield per plant, Nootripathu / PMK 3 exhibited significant standard heterosis for seven characters namely plant height, root length, root dry weight, root : shoot ratio, 100 grain weight, harvest index, and grain yield per plant were found to be superior hybrids over the standard check variety PMK 3. High proline content which is an index for drought tolerance was recorded in hybrid Kuruvaikalangiam / ADT 36 (11.94\%) exhibited significant standard heterosis which is found to be drought tolerant among the hybrids.

Keywords: Drought tolerance, Land race, Physico morphological traits, Significant standard heterosis

\section{INTRODUCTION}

Rice has been cultivated in more than 100 countries in variety of ecosystems around $163 \mathrm{~m}$ ha worldwide annually (FAO, 2013) of the world's cultivated land (Degenkolbe et al., 2013). Among the rice growing countries, the larger area (about 42.5 million ha, (FAO 2013) under cultivation is in India (Utharasu and Anandakumar, 2013). It has been estimated that the world will have to produce $60 \%$ more rice by 2030 than what it produced in the 1995. Therefore, to increase production of rice plays a very important role in food security and poverty alleviation. The rapid industrialization heralded the change in climate and eventually disturbed the steady state of cultivation statics of stable food crops like rice. Among the abiotic stress, drought is the major constrains to the rice production and yield stability in rainfed areas and 18 million tons of rice valued at US \$3600 is lost annually to drought (O'Toole, 1999). About $45 \%$ of the world's rice is cultivated in rainfed ecosystems (IRRI, 2002). Drought is the most important source of climate-related risk for rice production in rainfed areas (Dwivedi and Pandey, 2012). The increasing threat from water shortage and drought in many rice-growing areas of Asia, particularly the rainfed areas, has posed a great challenge to rice breeders to develop drought tolerant and/or water-saving rice cultivars (Zhao et al., 2008). Drought mitigation, through development of drought-resistant rice varieties with higher yields suitable for water-limiting environments will be a key to improve rice production and ensure food security to 3 billion people in Asia (Chandra Babu, 2010). Modern breeding programme targeted mainly on the improvement in yield and quality. Continuous cultivation and utilization of elite high yielding lines resulted in narrow down in the genetic bases. Inclusion of land races through introgression breeding solves the problem of genetic vulnerability. Because the land race and wild relatives are the potential source of gene for resistant to various stresses including drought (Xia et al., 2006). India has largest collection of rice land races and wild relatives spread around the country. Some of the traditional varieties has been conserved and cultivated by local farmers. Development of drought resistant cultivars will considerably improve rainfed rice production. Alternatively, yield improvements in water-limited environments can be achieved by selecting for secondary traits contributing to drought resistance in breeding programs (Liu et al., 2010). The significance of present investigation is to utilize the land races to produce superior heterotic combination and selection of promising hybrid with the use of secondary traits associated with drought tolerance. Here an attempt had been made to collect the drought tolerant land races to their genetic potential in the hybrids. 


\section{MATERIALS AND METHODS}

A set of 10 parents comprising of six drought tolerant landraces viz., Kallurundaikar, Kuliadichan, Kuruvaikalangiam, Mattaikar, Nootripathu and Vellaichithiraikar were utilized as lines and four high yielding rice varieties viz., PMK 3, MDU 5, ASD 16 and ADT 36 used as testers were obtained from various research stations in Tamil Nadu. In nursery three staggered sowings of all the parents were taken up at 10 days interval to facilitate synchronization in flowering. Crosses were effected in a 'Line x tester' mating design (Kempthorne, 1957) following wet cloth emasculation method suggested by Chaisang et al. (1967). The 24 hybrids effected with 10 parents were transplanted in two rows of $1.5 \mathrm{~m}$ length with a spacing of $20 \mathrm{~cm} \times 10 \mathrm{~cm}$ in a randomized block design (RBD) with two replications. Recommended package of practices and need based plant protection measures were done (Crop production guide, 2005). Moisture stress was induced by withholding irrigation for a period of 15 days during tillering stage starting on 60 days after sowing. The crop was irrigated after the stress period up to maturity. Observations were recorded for 13 physio-morphological traits like days to $50 \%$ flowering, plant height, productive tillers plant 1, grains panicle ${ }^{-1}, 100$ grain weight, harvest index, grain yield plant- ${ }^{1}$, chlorophyll stability index (CSI), root length, root dry weight, root : shoot ratio, relative water content and proline content on five randomly selected plants per line as per standard evaluation system for rice (IRRI, 1996). The Relative Water Content (RWC) was calculated using the formula suggested by Weatherly (1950). Chlorophyll stability index in leaf was estimated by Spectrophotometeric method as suggested by Koloyereas (1958). Proline content was estimated by colorimetric method as described by (Bates et al., 1973). The mean data derived from five plants per replication were subjected to statistical analysis and for the estimation of three types of heterosis (Fonseca and Patterson, 1968).

\section{RESULTS AND DISCUSSION}

To know the potentiality of hybrids, study on magnitude and direction of heterosis is important. A good hybrid should manifest high amount of heterosis for exploitation. Therefore selection based on high heterosis of more than one character will be highly realistic. Some workers suggested that there should be at least 20-30 per cent yield advantage for hybrids over the standard varieties to offset the cost of hybrid seed production (Virmani et al., 1982).

In practice, selection of productive hybrid is weighed not by the expression of heterosis over better parent, but in relation to the standard variety (Grakh and Chaudhury, 1985). Therefore the hybrids were evaluated based on standard heterosis over the standard check PMK $3\left(\mathrm{~T}_{1}\right)$ for all the traits and listed in the tables 1-5. Biju et al.(2006), reported, the presence of exploitable level of heterosis is yet another prerequisite for the success of hybrid breeding and is recognized as the genetic yield ceiling in areas where yields have already approached their potential. Negative heterosis is desirable for days to flowering and plant height because this will make the hybrids to mature earlier as compared to parents. While for other traits, positive significant standard heterosis effects were considered. Heterosis for earliness has been reported by Young and Virmani (1990) and Mishra and Pandey (1998). Significant negative standard heterosis for days to $50 \%$ flowering and plant height was also indicated by Pandya and Tripati (2006), Chaudhry et al., (2007), Kumar Babu et al. (2010) and Tiwari et al. (2011). For days to 50\% flowering six hybrids namely Kallurundaikar / ADT 36 (-8.16\%), Kuruvaikalangiam / ADT 36 (-13.88\%), Mattaikar / ADT 36 (-14.17\%), Nootripathu / MDU 5 (-13.78\%), Nootripathu / ASD 16 (-14.16\%) and Vellaichithiraikar / MDU 5 (-14.17\%) showed significant negative standard heterosis. Twenty hybrids exhibited better performance than the standard check for plant height. These results are in agreement with those obtained by Weerakoon et al. (2008), El-Mouhamady (2009) and El-Mouhamady et al., 2013. Positive heterosis was enviable for rest of the traits viz., Productive tillers per plant, Grains per panicle, Root length, Root dry weight, Root: Shoot ratio, Hundred grain weight, , Chlorophyll stability index, Harvest index, Relative water content, Proline content and grain yield per panicle. One hybrid (Kuruvaikalangiam / ADT 36 (11.94\%)) exhibited significant standard heterosis for proline content. Two hybrids (Nootripathu / PMK 3 (8.33\% and (7.50\%)) and Nootripathu / MDU 5 (25.00\% and (26.43\%)) alone exhibited heterotic vigour for root dry weight and root : shoot ratio. 13 hybrids out of 24 hybrids exhibited significant standard heterosis for 100 grain weight over the standard check. Kallurandaikar / PMK 3 (7.50 \%), Kuliadichan / PMK 3 (20.00\%), Nootripathu / PMK 3 (12.50\%), Nootripathu / MDU $5(15 \%)$ and Vellaichithiraikar / PMK $3(7.50 \%)$ exhibited significant standard heterosis for harvest index. For grain yield per plant Kallurundaikar / PMK 3 (9.42\%), Kuliadichan / PMK 3 (10.70\%), Nootripathu / PMK 3 (9.24\%), Nootripathu / MDU 5 (13.62\%), Vellaichithiraikar / PMK 3 (13.50\%) and Vellaichithiraikar / MDU 5 (15.56\%) exhibited significant standard heterosis. These findings were in close agreement with the earlier findings of Chandirakala et al., (2010), Kumar Babu et al. (2010), Chaitali Sen and Singh (2011) and Tiwari et al. (2011). Higher levels of heterosis for RWC, chlorophyll stability index, root length and root dry weight are desired for a genotype to be resistant to drought as revealed by the earlier workers (Michael and Rangasamy, 2002; Anbumalarmathi et al., 2005). Overall the hybrids Nootripathu / PMK 3 and 
R. Ushakumari et al. / J. Appl. \& Nat. Sci. 6 (2): 804 - 811 (2014)

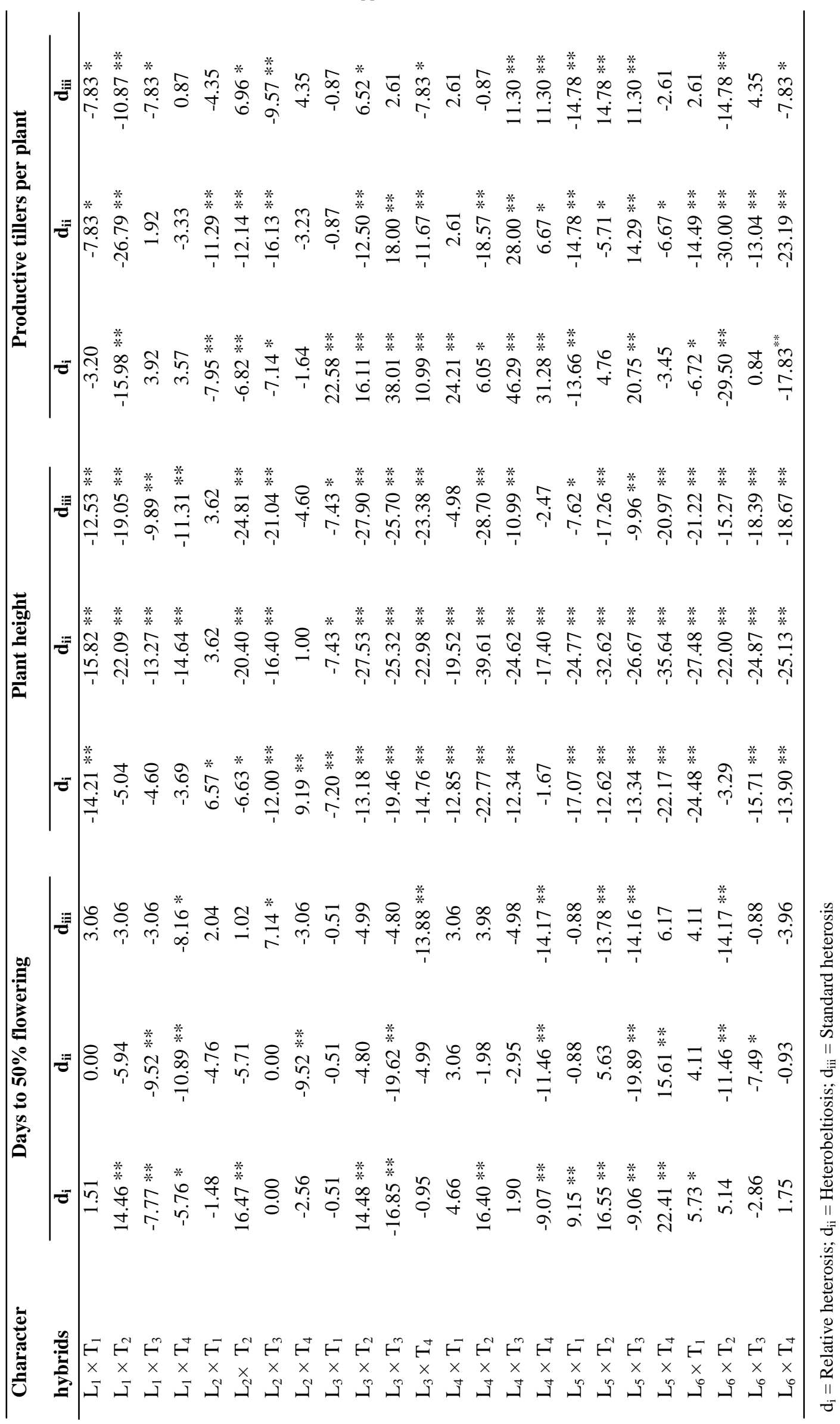




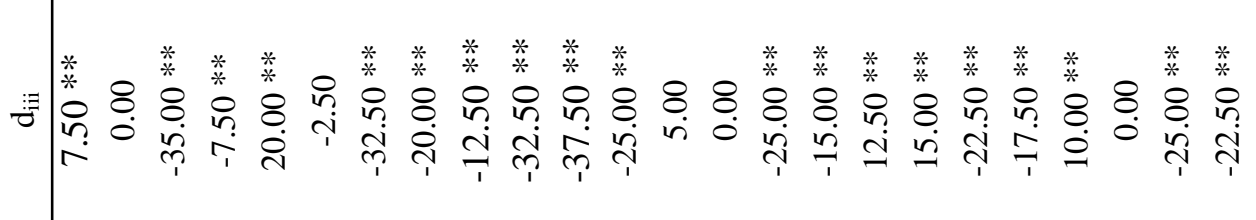

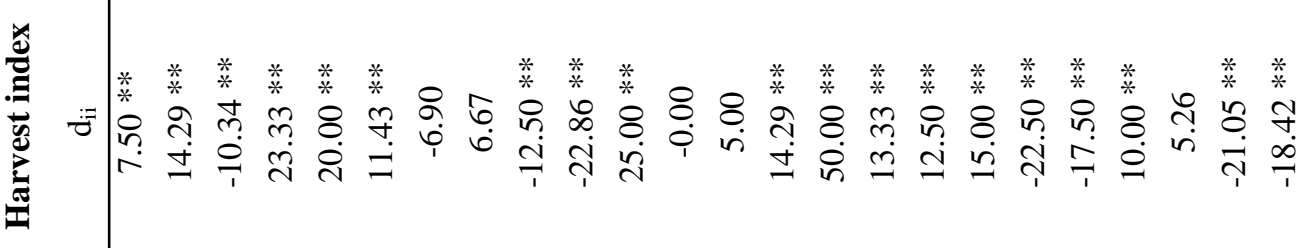

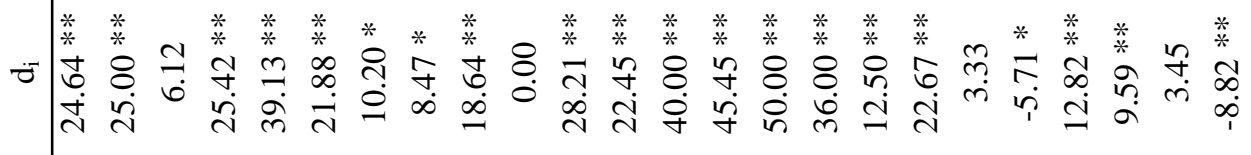

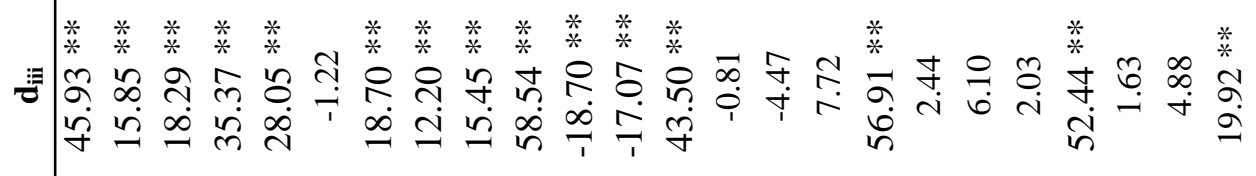

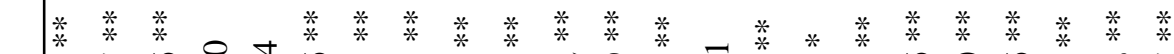

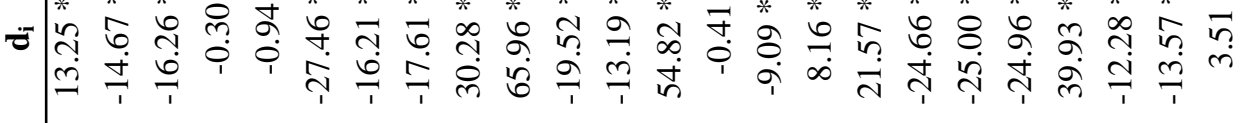

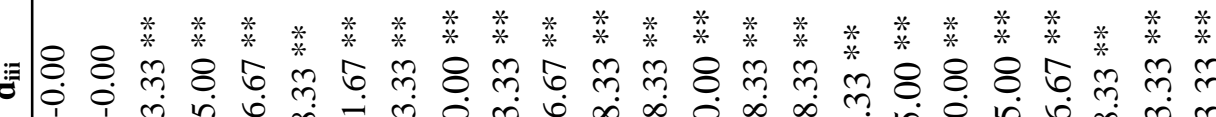

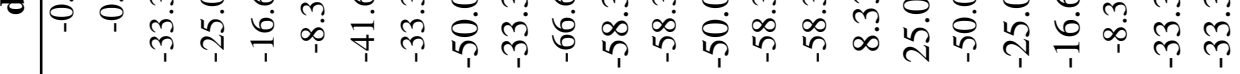

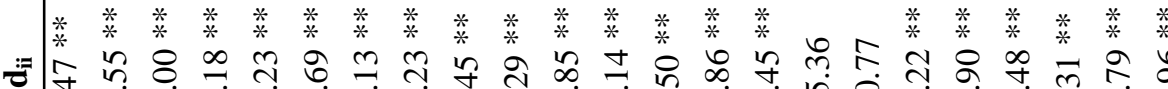

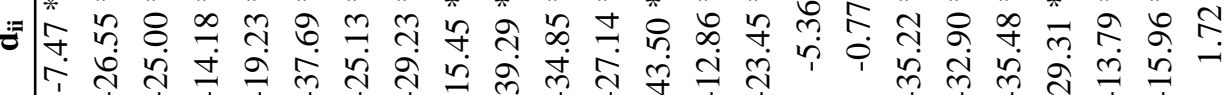

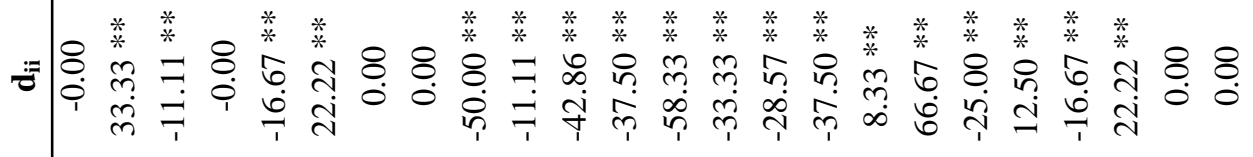

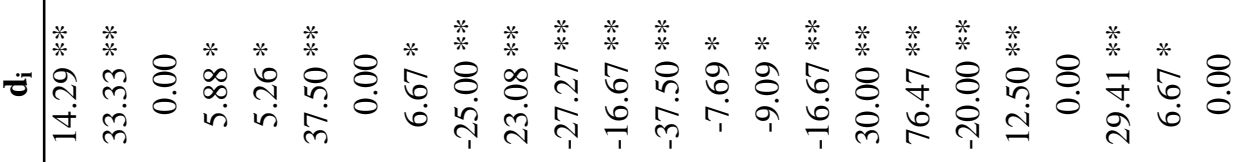


Table 5. Heterosis per cent for Grain yield per plant.

\begin{tabular}{|c|c|c|c|}
\hline \multirow{2}{*}{$\begin{array}{c}\text { Character } \\
\text { hybrids }\end{array}$} & \multicolumn{3}{|c|}{ Grain yield per plant } \\
\hline & $\mathbf{d}_{\mathbf{i}}$ & $\mathbf{d}_{\mathrm{ii}}$ & $\mathbf{d}_{\mathrm{iii}}$ \\
\hline $\mathrm{L}_{1} \times \mathrm{T}_{1}$ & $10.94 * *$ & $9.42 * *$ & $9.42 * *$ \\
\hline $\mathrm{L}_{1} \times \mathrm{T}_{2}$ & -1.42 & $-6.45 *$ & 1.34 \\
\hline $\mathrm{L}_{1} \times \mathrm{T}_{3}$ & 0.66 & $-14.44 * *$ & $-16.78 * *$ \\
\hline $\mathrm{L}_{1} \times \mathrm{T}_{4}$ & -0.20 & -4.88 & $-7.48 *$ \\
\hline $\mathrm{L}_{2} \times \mathrm{T}_{1}$ & $17.67 * *$ & $10.70 * *$ & $10.70 * *$ \\
\hline $\mathrm{L}_{2} \times \mathrm{T}_{2}$ & $-11.08 * *$ & $-19.36 * *$ & $-12.64 * *$ \\
\hline $\mathrm{L}_{2} \times \mathrm{T}_{3}$ & $-11.60 * *$ & $-21.66 * *$ & $-30.94 * *$ \\
\hline $\mathrm{L}_{2} \times \mathrm{T}_{4}$ & $-6.28 *$ & -6.28 & $-17.39 * *$ \\
\hline $\mathrm{L}_{3} \times \mathrm{T}_{1}$ & 1.97 & $-13.37 * *$ & $-13.37 * *$ \\
\hline $\mathrm{L}_{3} \times \mathrm{T}_{2}$ & 0.82 & $-17.06 * *$ & $-10.15 * *$ \\
\hline $\mathrm{L}_{3} \times \mathrm{T}_{3}$ & $14.10 * *$ & $12.61 * *$ & $-21.28 * *$ \\
\hline $\mathrm{L}_{3} \times \mathrm{T}_{4}$ & 2.00 & $-8.55 *$ & $-19.39 * *$ \\
\hline $\mathrm{L}_{4} \times \mathrm{T}_{1}$ & $-16.21 * *$ & $-30.09 * *$ & $-30.09 * *$ \\
\hline $\mathrm{L}_{4} \times \mathrm{T}_{2}$ & $-19.50 * *$ & $-34.90 * *$ & $-29.48 * *$ \\
\hline $\mathrm{L}_{4} \times \mathrm{T}_{3}$ & $12.61 * *$ & $11.61 * *$ & $-24.01 * *$ \\
\hline $\mathrm{L}_{4} \times \mathrm{T}_{4}$ & 3.06 & $-9.38 * *$ & $-20.12 * *$ \\
\hline $\mathrm{L}_{5} \times \mathrm{T}_{1}$ & $16.12 * *$ & $9.24 * *$ & $9.24 * *$ \\
\hline $\mathrm{L}_{5} \times \mathrm{T}_{2}$ & $15.66 * *$ & 4.88 & $13.62 * *$ \\
\hline $\mathrm{L}_{5} \times \mathrm{T}_{3}$ & $18.99 * *$ & 5.45 & $-7.05 *$ \\
\hline $\mathrm{L}_{5} \times \mathrm{T}_{4}$ & 3.52 & 3.52 & $-8.75 * *$ \\
\hline $\mathrm{L}_{6} \times \mathrm{T}_{1}$ & $18.73 * *$ & $13.50 * *$ & $13.50 * *$ \\
\hline $\mathrm{L}_{6} \times \mathrm{T}_{2}$ & $15.84 * *$ & $6.68 *$ & $15.56 * *$ \\
\hline $\mathrm{L}_{6} \times \mathrm{T}_{3}$ & $6.95 *$ & $-6.60 *$ & $-14.83 * *$ \\
\hline $\mathrm{L}_{6} \times \mathrm{T}_{4}$ & $7.73 * *$ & 5.93 & -3.40 \\
\hline
\end{tabular}

$\mathrm{d}_{\mathrm{i}}=$ Relative heterosis; $\mathrm{d}_{\mathrm{ii}}=$ Heterobeltiosis; $\mathrm{d}_{\mathrm{iii}}=$ Standard heterosis

Vellaichithiraikar / PMK 3 were found to be drought tolerant for twelve characters studied. From these studies it was clear that many number of the traits related to yield and those promoting drought tolerance governed by non-additive gene action. Hence it is excel the hybrids excel the standard variety in many number aspects. Earlier workers Dwivedi and Pandey (2012) and Manonmani and Fazlullah Khan (2003) reported the presence of non-additive gene action for grain yield and most of the yield contributing and drought tolerant traits in the hybrids resulted in high amount of vigour in F1 indicating the possibility of augmenting yield and drought tolerance by exploiting heterosis. These hybrids may be utilized for future breeding program for development of drought tolerance lines. Thus parents producing non-heterotic hybrids for days to $50 \%$ flowering and plant height may be preferred while aiming to produce drought tolerance hybrids.

\section{Conclusion}

These findings enable to select the hybrids viz.,
Nootripathu / MDU 5, which had significant standard heterosis for eight characters namely days to $50 \%$ flowering, plant height, productive tillers, root length, root dry weight, root : shoot ratio, harvest index and grain yield per plant, Nootripathu / PMK 3 exhibited significant standard heterosis for seven characters namely plant height, root length, root dry weight, root : shoot ratio, 100 grain weight, harvest index, and grain yield per plant and Vellaichithiraikar / PMK 3 which had significant standard heterosis for five traits namely plant height, root length, 100 grain weight, harvest index and grain yield per plant were the superior hybrids over the standard check variety and they may be utilized for future breeding program for development of drought tolerance lines. High proline content which is an index for drought tolerance was recorded in hybrid Kuruvaikalangiam / ADT 36 (11.94\%) exhibited significant standard heterosis which is found to be drought tolerant among the hybrids .

\section{REFERENCES}

Anbumalarmathi, J., A. Sheeba, and P. Deepasankar. (2005). 
Genetic variability and interrelationship studies in cowpea (Vigna unguiculata (L.) Walp.), Res. Crops., 6 (3): 517-519.

Bates, L.S., R.P. Waldren, and L.D. Teare. (1973). Rapid determination of free proline for water stress studies. Plant and Soil., 39: 205-207.

Biju, S., Manonmani, S., Thiyagarajan, K., Thiyagu,K., Abirami, S. and Mohanasundaram, K. (2006). Studies on heterosis for yield and related characters in rice hybrids. Plant Arch., 6(2): 549-551.

Chaisang, K., B.W. Ponnaiya, and K.M. Balasubramanian. (1967). Studies on anthesis, pollination and hybridization technique in rice (Oryza sativa L.). Madras Agric. J., 54: 118-123.

Chaitali Sen and R.P. Singh. (2011). Study on heterosis in Boro x High yielding rice hybrids. Int. J. Pl. Br. Genet., 5(2): 141-149.

Chandirakala, R., Kandasamy, G. and Thiyagarajan, K. (2010). Heterotic expression of two line hybrids in rice. Oryza., 47(3): 248-251.

Chandra Babu, R. (2010). Breeding for drought resistance in rice: an integrated view from physiology to genomics. Electronic Journal of Plant Breeding., 1(4): 1133-1141.

Chaudhry, A., P. Sharma., H. Singh., S. K. Pradhan, and M.P. Pandey. (2007). Study on heterosis for yield and physiological characters in rice hybrids. Oryza., 44(1): 7 -13 .

Crop production guide. (2005). Tamil Nadu Agricultural University, Coimbatore. Page No, 15-18.

Degenkolbe, T., T. Do Phuc., Joachim Kopka., Ellen Zuther., Dirk K. Hincha., Karin, and I. Kohl. (2013). Identification of drought tolerance tarkers in a diverse population of rice cultivars by expression and metabolite profiling. PLOS One., 8(5): 1-14.

Dwivedi, D. K. and Pandey, M. P. (2012). Gene action and heterosis for yield and associated traits in Indica and tropical japonica crosses of rice (Oryza sativa L.) involving wide compatibity genes. Int. J. Plant Breed. Genet., 6(3): 140-150.

El-Mouhamady, A.A. (2009). Breeding for drought tolerance in rice. Ph.D. Thesis, Fac. Agric., Kafrel-sheikh Univ., Egypt.

El-Mouhamady, A.A., Abdel-Sattar, A.A. and El-Seidy, E.H. (2013). Assessment the degree of drought tolerance in rice through the environmental tests and molecular markers technique. Research Journal of Agriculture and Biological Sciences., 9(1): 40-57.

Fonseca, S. and F.L. Patterson. (1968). Hybrid vigor in a seven-parent diallel crosses in common winter wheat. Crop Sci., 8: 85-88.

Food and Agriculture Organization. (2013). The state of food and agriculture. Food and agriculture organization of the United Nations, Rome, Page No, 3-12.

Grakh,S.S. and M.S. Chaudhary. (1985). Heterosis for early maturing and high yield in Gossypium arboreum. Indian J. Agric. Sci., 55:10-13.

IRRI (1996). Standard Evaluation System for Rice. Fourth edition. International Rice Research Institute, Manila, The Philippines.

IRRI (2002). standard evaluation system of rice (SES). International rice research institute. Manila, The
Philippines.

Kempthorne, O. (1957). An introduction to genetic studies. John Wiley and Sons Inc., New York.

Koloyereas, S.A. (1958). A new method for determining drought resistance. Plant Physiol., 33: 232-233.

Kumar Babu, G., P.V. Satyanarayana., C. Panduranga Rao, and V. Srinivasa Rao. (2010). Heterosis for yield, components and quality traits in rice (Oryza sativa $\mathrm{L}$.). Andhra Agric. J., 57(3): 226-229.

Liu T., D. Shao., M.R. Kovi, and Y. Xing. (2010). Mapping and validation of quantitative trait loci for spikelets per panicle and 1,000-grain weight in rice (Oryza sativa L.). Theor. Appl. Genet., 120:933-942.

Manonmani, S. and A. K. Faslullah Khan. (2003). Studies on combining ability and heterosis in rice. Madras Agric. J., 90(4-6): 228-231.

Michael Gomez, S. and P. Rangasamy. (2002). Correlation and path analysis of yield and physiological characters in drought resistant rice (Oryza sativa L.). Int. J. Mendel., 19(1-2): 33-34.

Mishra, M. and M.P. Pandey. (1998). Heterosis breeding in rice for irrigated sub humid tropics in North India. Oryza., 35: 8-14.

O'Toole. (1999). Molecular Approaches for the Genetic Improvement of Cereals for Stable production in Water limited Environments. In: A Strategic planning Workshop. Ribaut, J.M. and D. Poland (Eds.). CIMMYT, El Batan, Mexico.

Pandya, R. and R.S. Tripati. (2006). Heterosis breeding in hybrid rice. Oryza. 43(2): 87-93.

Tiwari, D. K., P. Pandey., S.P. Giri, and J.L. Dwivedi. (2011). Heterosis studies for yield and its components in rice hybrids using CMS system. Asian J. Plant Sciences. 10(1): 29-42.

Utharasu, S. and C. R. Anandakumar. (2013). Heterosis and combining ability analysis for grain yield and its component traits in aerobic rice (Oryza sativa L.) cultivars. Electronic Journal of Plant Breeding., 4(4): 1271-1279.

Virmani, S.S., Aquino, R. C. and Khush, G.S. (1982). Heterosis breeding in rice, Oryza sativa (L.). Theor. Appl. Genet., 63: 373-380.

Weatherly, P.E. (1950). Studies in the water relations of the cotton plant. I. The field measurements of water deficits in leaves. New Physiol., 49: 81.

Weerakoon, W. M. W., Maruyama, A. and Ohba, K. (2008). Impact of humidity on temperature induced grain sterility in rice (Oryza sativa L.). Rice Research and Development Institute, Bata.

Xia,Z., Z. Shaoxia., F. Yongcai., S. Zhen., W. Xiangkun, and S. Chuanqing. (2006). Identification of a drought tolerant introgression line derived from Dongxiang common wild rice (O. rufipogon Griff.). Plant Molec. Biol., 62: 247-259.

Young, J. and S.S. Virmani. (1990). Heterosis in rice over environments. Euphytica. 51: 87-93.

Zhao, X.Q., Xu, J. L., Zhao, M. R., Lafitte., L. H. Zhu., B. Y. Fu., Gao, Y. M. and Z. K. Li. (2008). QTLs affecting morphysiological traits related to drought tolerance detected in overlapping introgression lines of rice (Oryza sativa L.). Plant Science., 174: 618-625. 